\title{
New corpus-linguistic approaches to the investigation of poetic occasionalisms: The case of Johann Nepomuk Nestroy
}

\author{
Wolfgang U. Dressler and Barbara Tumfart \\ Austrian Academy of Sciences, Vienna \\ wolfgang.dressler@univie.ac.at
}

\begin{abstract}
This paper reports on new approaches to the analysis of poetic occasionalisms, i.e. of words created by an author for a specific place in a literary text, and exemplifies them with the occasionalisms found in three comedies by Johann Nepomuk Nestroy, the greatest Austrian comedy writer and creator of new words in the 19th century. Corpuslinguistic search in Nestroy's complete works and in large German electronic corpora enables better decisions with regard to whether an unfamiliar word was really an occasionalism. Comparison with Nestroy's French models (never done so far) shows that these occasionalisms are really Nestroy's original creations. Two new analyses of their relative audacity offer novel insights, which are corroborated by a first comparison between Nestroy's and a rival's occasionalisms. Next, the results of a cotextual and contextual analysis of occasionalisms are offered. Finally, for the first time it is studied to which actors the presentation of most occasionalisms was assigned in order to achieve optimal theatrical effects.
\end{abstract}

Keywords: poetic language; occasionalism; Nestroy; corpus linguistics.

\section{Introduction}

The interest of linguists in poetic and literary language in general has an old and prominent tradition - for example Watkins (2001) in Indo-European linguistics, Spitzer (1910) in Romance linguistics, and Jakobson (1960) and Coseriu (1971) in structural linguistics, the latter insisting that literary writers are capable of exhausting the potentialities of a language to a greater extent than non-literary writers. For generative linguistics, we can name Bierwisch (1965), who adapted to this model the focus on poetic deviations from "normal" language, an approach inherent in the Prague School concept of alienation, prized by Mukarovsky (1970). For Russian linguistics, one must name Chanpira (1966), who 
coined the term occasionalism, meaning a new word created for a poetic function at a specific place in a literary text, and which has little chance to be accepted by the language community as a neologism (more in Zemskaja 1973: 227-240).

Dressler (1981a, 1983, 2007b) endeavoured to create and elaborate a linguistic scale of poetic audacity of occasionalisms as characterizing poetic license, thereby aiming to account for poetic creativity in the realm of word formation. But this can cover only the paradigmatic axis of occasionalisms, whereas for the syntagmatic axis efforts were limited to textlinguistic aspects of cohesion created by occasionalisms either in anaphoric or cataphoric function (Dressler 1981b; Dressler and Mörth 2012).

However, now a co-author has been found for work on the larger syntagmatic aspects - the second author of the present paper, a literary expert specializing in 19th-century Viennese comedy, including its most important representative, Johann Nepomuk Nestroy (1801-1862); cf. Tumfart (2005, 2008, 2012). Therefore, we would like to exemplify our new approach and our new methods with this comedy writer and with his role in the contemporary literature of his time. Since Nestroy's works are still cherished (and thus performed in theatres) for their satirical, jocular and creative use of the lexicon (cf. Hein 1970; Scheichl 2001), and since he is unanimously considered to be the greatest Austrian creator of new words in the whole 19th century, an investigation of his occasionalisms seemed promising. Since the superlative greatest creator is relative, his occasionalisms must be systematically related to the productions of other writers, which has never been done before.

Our approach is corpus-linguistic and, with the expansion of electronic corpora, it allows us to inspect new data and to pose and answer new questions in the study of occasionalisms created by poets for a single use at a specific point in one of their texts (cf. Christofidou 1994). Such research can surpass the limits of, e.g., recent studies on James Joyce and on other writers, such as Boase-Beier (1987) or of all the previous studies on Johann Nepomuk Nestroy (Gengnagel 1962; Kreissler 1967; Hunger 1999; Panagl 1983, 2007), including those by Dressler (1981a, 1983, 2007b).

\section{Data and methods}

We studied all the occasionalisms found in three Nestroy comedies (Das Mädl aus der Vorstadt, Das Gewürzkrämer-Kleeblatt, and Der Zerrissene, henceforth 
abbreviated as Mädl, Gewürz, Zerriss) and compared them with: (1) the whole electronic corpus of Nestroy's works available at the Austrian Academy of Sciences (also with the historical-critical edition by Hein et al. 1977-2010); (2) the Academy's electronic corpus of contemporary Viennese comedies (Viennese Theatre Corpus, henceforth VTC (over 750,000 word tokens); (3) the electronic historical Austrian Academy Corpus (AAC) composed of texts starting in 1848 (over 500 million tokens); and (4) the electronic historical corpus of the Deutsches Text Archiv (DTA, over 100 million tokens). We used the Academy's tools, notably the word-splitter.

The systematic comparison of Nestroy's occasionalisms that we pioneered can be divided into several steps (Sections 3-8).

\section{Is a putative occasionalism really an occasionalism?}

The identification of occasionalisms usually starts with introspectivism: a complex or derived word, unknown to a linguist, found in a literary work, strikes the linguist as a possible occasionalism created by the literary author, because creating occasionalisms is part of poetic license typical of many authors. This is a necessary first, creative step, but an investigator must not stop here (as Hunger 1999 largely did in his monograph). The reliability of introspective judgments on putative occasionalisms is small, especially with literary works produced in the mid-19th century. Thorough controls are necessary, and for this purpose we ploughed through electronic corpora, which had not been possible for the authors cited in Section 1.

By means of searching through the above-mentioned electronic corpora, we first established whether Nestroy used (a candidate for) an occasionalism really only once in his many comedies, and then determined whether it did not occur elsewhere in 19th-century or earlier writings. The first search results in certainty, the second search only in high probability, because the existing electronic corpora are by far not exhaustive for the 18th and 19th century (earlier authors were not read by intellectuals like Nestroy). But the probability of correctly identifying an occasionalism by electronic, corpus-linguistic means is much higher than by looking through dictionaries and the few existing glossaries of single authors.

This can be illustrated with a few problematic examples. In $M \ddot{a} d l$ II.12, one finds the expression 
(1) mit unsrer Dräng+er Schar 'with our pushers' band'

The deverbal agent noun occurs only here within Nestroy, contemporary comedies (VTC) and earlier texts, but it recurs soon afterwards and again with its head noun Schar 'band' in a socialist song and in a text by the early protagonist of the German workers' movement Ferdinand Lassalle. Are these recurrences and Nestroy's phrase independent continuations of an earlier hidden tradition? We decided that here we are dealing with citations from Nestroy, who was very popular in the workers' movement because of his well-known accounts of daily lower-class life and because of his frequent satirical criticism of capitalism. Similarly, we assume that, in 1853 , the much less prominent comedy writer Georg Köberle copied Nestroy's 1845 occasionalism in (2):

$$
\text { Eh'stand }+s+\text { lotterie 'matrimonial lottery' (Gewürz I.15) }
$$

As the final example in this section, the adjective

$$
\text { normal }+ \text { mäßig, a synonymous extension of normal 'normal' }
$$

occurs only once in Nestroy (Mädl II.7) and never in VTC, but has 56 tokens in $\mathrm{AAC}$, and is thus not an occasionalism.

\section{Is an occasionalism Nestroy's original creation or a translation from French?}

Because of the intense demand for new comedies, both Nestroy and his contemporary Viennese comedy writers used to study new French comedies and translated them into German. Nestroy wrote more than one third of his comedies after French models, including the three investigated by us: Das Mädl aus der Vorstadt (1841) was modelled after Paul de Kock et Varin's La Jolie Fille du faubourg (1840); Der Zerrissene (1844) - after Duvert et Lauzanne's L'Homme blasé (1843); and Das Gewürzkrämer-Kleeblatt (1845) - after Lockroy et Anicet-Bourgeois' Trois Épiciers (1840). But these were very creative translations, or rather "creative adaptations" (Yates 2008: 44, 51-68; Doering 1994: 31-44). Nestroy often changed the text considerably and created new dialogues and monologues (Yates 1972: 121ff; Preisner 1968:41ff). 
First of all, we carefully read these three French comedies, but found no single occasionalism - only well-known, well-established French words. Second, Nestroy placed his occasionalisms almost always in text chunks created by himself, beyond his French models. Third, there are only four occasionalisms which render a French phrase, compound or derivation. For example, in the parodistic

(4) in der an + ge + vers $+e l+t+e n$ Landnatur (Zerriss II 9) 'in the versified rural nature',

the diminutive verbal suffix -el renders connotatively the denotation of the adjective in the French model

(5) l'affreuse bucolique 'the horrible bucolics' (L'homme blasé II 5).

In Mädl II.15, Nestroy changed

(6) coquett-erie (La Jolie Fille III.1) (which had been loaned into G. Kokett+erie earlier) into the ungrammatical

(7) Kokett+ur.

Thus, Nestroy's occasionalisms are due to his own creativity.

\section{The degree of audacity of Nestroy's occasionalisms}

Authors dealing with Nestroy's occasionalisms have generally considered them to be rather audacious, with the implicit consequence that this great degree of poetic license was supposed to distinguish Nestroy from his contemporary rivals. Our own analysis investigates the occasionalisms of his three plays investigated on two linguistic dimensions, discussed in Sections 5.1 and 5.2.

\subsection{Degree of audacity of word-formation rules represented by occasionalisms}

Firstly, we classified the audacity of his occasionalisms according to the methodology successively developed in Dressler (1981a, 1983, 2007b), which allows a (simplified) grading of the use of word-formation patterns in creating occasionalisms: from most audacious (ungrammatical (illegal) creations) to auda- 
cious (use of unproductive rules) to not audacious (use of fully productive rules).

Contrary to previous, insufficiently systematic studies, we found that Nestroy nearly always used current productive word-formation rules for creating occasionalisms, i.e. in 99 of the 102 occasionalisms occurring in the three plays studied. These include, in particular:

(a) 19 concatenative (non-interfixed) noun compounds, e.g.

(8) Podagra+füß ' 'podagra feet' (Mädl I.6);

(b) 23 interfixed noun compounds, e.g.

(9) Kapitalist+en+gefühl 'capitalist feeling' (Mädl I.6);

(c) $19 \mathrm{phrase} /$ sentence/synthetic compounds, e.g.

(10) Glück+zerstör+er 'happiness destroyer';

(d) 3 diminutives, e.g.

(11) Bräutigamm $+l$ 'bridegroom-ie';

plus other derivations with even smaller numbers. Thus, Nestroy's occasionalisms are dominated by compounds (62 of 99).

The only unproductive formation is the compound verb

$$
\text { zorn+erbleichen 'to become pale for rage', }
$$

and there are just 2 ungrammatical occasionalisms:

(13) Kokett+ur (see Section 4), and

(14) All $+e+$ tag + s + genüsse 'every day delights' (Zerriss I.5).

\subsection{Conspicuousness of element combinations}

Secondly, we investigated the compound families (of Nestroy's occasionalistic compounds) consisting of the same lexical compound member in the same position in all the electronic corpora available and found two salient properties. 
Firstly, we identified occasionalistic compounds which consisted of two elements of which at least one belongs to families with very small family size, which means that these two elements normally have extremely little chance of being combined (Hay and Baayen 2002; Mulder et al. 2014), e.g.

$$
\text { Mathilden+schnipfer 'stealer of Mathilde'. }
$$

The second part of (15) was found only in three other compounds, while the first part, being as a name, is an ad-hoc argument of the regional verb schnipfen.

Secondly, we found compounds with both elements belonging to large families, but whose combination is semantically surprising, because there do not exist such combinations (even not semantically similar ones). For example, in

$$
\text { Liebe }+s+\text { mathematiker (Mädl II.15) ‘love mathematician’ }
$$

neither the first nor the second member occurs with semantically similar other members in the other position. We have found

$$
\text { Liebesmathematik, Liebesgeometrie 'love mathematics/geometry' }
$$

only in texts of the 21 st century. Another case is the gapping construction of

$$
\text { Knie- und Ferse + } n+\text { distanz 'knee and heel distance' (Mädl I.8) }
$$

where the combination of distance with body parts is highly unusual. This may be seen as Nestroy's specification of a property of comedies in general, as stated by Fludernik (2015): "The comedy [...] resides in the clash of depicted elements, in the incongruity of the blended worlds".

\section{Cotextual and contextual motivation of occasionalisms}

We also undertook the first systematic study of the cotextual and contextual motivation of Nestroy's novel words.

Nestroy usually motivates his occasionalisms in the preceding or following text chunk, i.e. by the cotext, and - as expected - more often anaphorically than cataphorically; the distance between the motivating cotext and the occasionalism is usually very small. These two tendencies represent, in a semiotic perspec- 
tive, two clear indexical preferences (Dressler 1989, 2000). One example is in Zerriss II.9:

(19) wärst du seine indirecte Mörderin, Tod+geber+in par distance 'you would be his murderess, his distant death-giveress'.

Multiple motivation occurs in Gewürz II.7: after the verb stehlen 'to steal' and its past participle gestohlen, we find

(20) Einen andern Diebstahl zeigt man an. - Bey der Frau+en+entwendung blammirt man sich, wenn man ein G'schrey macht. 'One reports (to the police) a different theft. - In case of a woman-purloining one disgraces oneself if one screams.'

Often, two occasionalisms are combined, e.g.

(21) Glück+zerstör+er, Seeligkeit+vernicht+er (Zerriss I.17) 'happiness destroyer, bliss exterminator'.

The contextual motivation, by embedding of occasionalisms in theatrically effective context, can be exemplified with the above-mentioned parodistic

(22) in der an + ge + vers $+e l+t+e n$ Landnatur (Zerriss II 9) 'in the versified rural nature',

which together with the adjacent occasionalism

Stereotip+igkeit 'stereotypicity'

belittles the excessive nature enthusiasm of 19th-century romanticism.

\section{Comparison of Nestroy's occasionalisms with those of his rival Berg}

We systematically compared, according to the dimensions of Sections 5 and 6 , all occasionalisms of Nestroy's three comedies with all the occasionalisms found in four comedies by Ottokar Franz Ebersberg: Ein Rekrut von 1859 
(1859), Die alte Schachtel (1856), Der barmherzige Bruder (1874) and Wiener Karrikaturen (1880). Ebersberg (1833-1886), also known as Berg, was a very fertile comedy writer and journalist of his time, but is now totally obsolete.

In contrast to Nestroy's 102 occasionalisms within the 56,760 word tokens of his three plays, we found only 25 occasionalisms within the 93,668 word tokens of the four plays by Berg. Thus, in percentage terms, Berg produced slightly more than a quarter of the number of Nestroy's occasionalisms, all of them representing productive word formation patterns.

Thus, Berg created many fewer occasionalisms than Nestroy (Section 5.1). With reference to the phenomena discussed in Section 5.2, we found only 3 occasionalisms in Berg's plays which are conspicuous for their combination of elements, e.g.

$$
\text { Zehe }+n+\text { schweb+erei (Alte Schachtel II 12) 'toe floating'. }
$$

While there are many compounds starting with Zehe 'toe', we could not find any compound ending in -schweberei.

In regard to cotextual and contextual motivation, Berg is by far inferior to Nestroy. There are few cotextual motivations and a literary analysis of contextual motivation in Tumfart and Dressler (2016) confirmed the great difference in the literary evaluations of Nestroy and Berg.

\section{Which actors were intended to present occasionalisms in Nestroy's plays?}

Finally, we compared the percentages of occasionalisms assigned to the different characters of his plays and found that the highest percentage of occasionalisms (among all the word tokens of each actor) were to be uttered by Nestroy himself, and next by his most esteemed actor-friend Wenzel Scholz, followed by his other esteemed actor friends Alois Grois and Carl Carl, according to who was supposed to act besides Nestroy himself in each comedy. This means that he entrusted his occasionalisms to the actors whose performance he trusted most. There is no trace of any possible connection between a high percentage of occasionalisms and a property which would unite these roles in the plays. This analysis, of a kind which - we think - has never been done before, proves Nestroy's strategic creation of occasionalisms on a metalinguistic level. 


\section{Conclusion}

Above all, Nestroy appears to have formed occasionalisms with a view to increasing the theatrical effect of word play and stimulating metalinguistic reflection, in ways partially similar to the effects already present in the occasionalisms created by Aristophanes (cf. Peppler 1902; Bergson 1900).

What our study exemplifies are novel results obtained by novel research methods: the confirmation of putative creative poetic words as really new creations by an author due to systematic investigation of large electronic corpora, the judicious systematic analysis of the make-up of occasionalisms according to their word-formation patterns and the interrelations between the compound families to which the constituents of an occasionalism belong, and the characterisation of the properties of a literary writer not in isolation but in comparison with similar authors (be it of the same or a different language). Linguists can learn how the potentialities of a language are exploited by its most creative native speakers. Literary scholars can be provided with new types of data which go beyond anecdotal selection of examples and allow them to study the cotextual and contextual motivation of poetic word creations. And to theatre experts, we have offered in Section 8 a new method for studying the strategic assignment of creative language to the actors most trusted by an author for achieving the intended theatrical effects. In this way, a corpus-linguistic analysis of belleslettres can provide new impulses for literary studies.

\section{References}

Bergson, H. 1900. Le rire: Essai sur la signification du comique. Paris: Éditions Alcan 1924. (Reprinted from Revue de Paris, $1^{\mathrm{er}}$ février, 15 février et $1^{\mathrm{er}}$ mars 1900.)

Bierwisch, M. 1965. "Poetik und Linguistik". In: Ihwe, J. (ed.), Literaturwissenschaft und Linguistik. Ergebnisse und Perspektiven. Frankfurt: Athenäum. 568-586.

Boase, J.B. 1987. Poetic compounds: The principles of poetic language in modern English poetry. Tübingen: Niemeyer.

Chanpira, E.I. 1966. "Ob okkazional'nom slove i okkazional'nom slovoobrazovanii" [On the occasional word and occasional word formation]. In: Zemskaja, E.A. and D.N. Šmelev (eds.), Razvitie slovoobrazovanija sovremennogo russkogo jazyka [The development of word formation in Modern Russian]. Moskva: Nauka.

Christofidou, A. 1994. Okkasionalismen in poetischen Texten: Eine Fallstudie am Werk von O. Elytis. Tübingen: Narr.

Coseriu, E. 1971. “Thesen zum Thema 'Sprache und Dichtung”’. In: Stempel, W. (ed.), Beiträge zur Textlinguistik. München: Fink. 183-188. 
Doering, S. 1992. Der Wienerische Europäer: Johann Nestroy und die Vorlagen seiner Stücke. München: W. Ludwig Verlag.

Doering, S. 1994. "Es ist alles uralt, nur in andrer Gestalt: Über die Vorlagen von Nestroys Werken". In: Yates, W.E. (ed.), Vom schaffenden zum edierten Nestroy. Wien: Jugend und Volk. 31-44.

Dressler, W.U. 1981a. “General principles of poetic license in word formation”. In: Geckeler, H., B. Schlieben-Lange, K. Trabant and H. Weydt (eds.), Logos semantikos. Studia linguistica in honorem Eugenio Coseriu 1921-1981. (Vol. 2: Sprachtheorie und Sprachphilosophie.) Berlin: de Gruyter. 423-431.

Dressler, W.U. 1981b. "Zum Verhältnis von Wortbildung und Textlinguistik (mit Beispielen aus der schönen Literatur)”. In: Petőfi, J. (ed.), Text vs. sentence continued. Hamburg: Buske. 96-106

Dressler, W.U. 1983. "Konsequenzen einer polyzentristischen Sprachtheorie für die Stiltheorie der dichterischen Sprache". Etudes Finno-Ougriennes 15. 117-131.

Dressler, W.U. 1989. Semiotische Parameter einer textlinguistischen Natürlichkeitstheorie. Wien: Verlag der Österreichischen Akademie der Wissenschaften.

Dressler, W.U. 2000. “Textlinguistik und Semiotik”. In: Brinker, K. et al. (eds.), Textund Gesprächslinguistik (vol. 1). Berlin: de Gruyter. 762-772.

Dressler, W.U. 2007a. "Productivity in word formation". In: Jarema, G. and G. Libben (eds.), The mental lexicon: Core perspectives. Amsterdam: Elsevier. 159-183.

Dressler, W.U. 2007b. "Produktivität und poetische Lizenz". In: Dressler, W.U. and O. Panagl (eds.), Poetische Lizenzen. Wien: Praesens Verlag. 117-132.

Dressler, W.U. and K. Mörth. 2012. "Produktive und weniger produktive Komposition in ihrer Rolle im Text an Hand der Beziehungen zwischen Titel und Text". In: Gaeta, L. and B. Schlücker (eds.), Das Deutsche als kompositionsfreudige Sprache. Berlin: de Gruyter. 219-233.

Fludernik, M. 2015. "Blending in cartoons: The production of comedy". In: Zunshine, L. (ed.), The Oxford handbook of cognitive literary studies. Oxford: Oxford University Press. 155-175.

Gengnagel, D. 1962. “Zur sprachlichen Gestaltung der Possen Johann Nestroys”. Wissenschaftiche Zeitschrift der Friedrich-Schiller-Universität Jena, Gesellschafts-und Sprachwissenschaftliche Reihe 1. 119-130.

Hay, J. and H. Baayen. 2002: "Parsing and productivity". Yearbook of Morphology 2001. 203-235.

Hein, J. 1970. Spiel und Satire in der Komödie Johann Nestroys. Bad Homburg: Gehlen.

Hein, J. 2012. "'Die Handlung ist dem Französischen nachgebildet': Johann Nestroy und seine Vorlagen im Spiegel der neuen historisch-kritischen Ausgabe". Austriaca 75. 15-39.

Hunger, H. 1999. Das Denken am Leitseil der Sprache: Johann Nestroys geniale wie auch banale Verfremdungen durch Neologismen. Wien: Verlag der Österreichischen Akademie der Wissenschaften.

Jakobson, R. 1990. "Linguistics and poetics". In: Sebeok, T. (ed.), Style in language. Cambridge, MA: MIT Press. 350-377.

Kreissler, F. 1967. Das Französische bei Raimund und Nestroy. Wien: Notring.

Mukarovsky, J. 1970. "Standard language and poetic language". In: Freeman, D.C. (ed.), Linguistics and literary style. New York: Holt, Rinehart and Winston. 40-56. 
Mulder, K., T. Dijkstra, R. Schreuder and R.H, Baayen. 2014. "Effects of primary and secondary morphological family size in monolingual and bilingual word processing". Journal of Memory and Language 72. 59-84.

Murat, J. 2015. "Lexical creativity". In: Jones, R.H. (ed.), The Routledge handbook of language and creativity. London: Routledge. 92-106.

Panagl, O. 1983. "(De-)Lexikalisierung und Paretymologie im Wortschatz Johann Nestroys". In: Dardano, M. (ed.), Parallela. Akten des 2. österreichisch-italienischen Linguistentreffens. Tübingen: Narr. 64-79.

Panagl, O. 2007. "Poetische Lizenzen in der Wortbildung”. In: Dressler, W.U. and O. Panagl (eds.), Poetische Lizenzen. Wien: Praesens Verlag. 117-132.

Peppler, C.W. 1902. Comic terminations in Aristophanes and the comic fragments: Diminutives, character names, patronymics. Baltimore: John Murphy Co.

Scheichl, S.P. 2001. "Er kraxelt in sein Verderben. Nestroys Sprachwitz". In: Die Welt steht auf kein Fall mehr lang, Johann Nestroy zum 200. Geburtstag, Katalog zur 277. Sonderausstellung des Historischen Museums der Stadt Wien gemeinsam mit der Wiener Stadt- und Landesbibliothek. Wien: Historisches Museum der Stadt Wien. 111-122.

Schultink, H. 1961. "Produktiviteit als morfologisch fenomeen" [Productivity as a morphological phenomenon]. Forum der Letteren 2. 110-125.

Spitzer, L. 1910. Die Wortbildung als stilistisches Mittel exemplifiziert an Rabelais. Nebst einem Anhang über die Wortbildung bei Balzac in seinen: Contes Drolatiques. Tübingen: Niemeyer

Tumfart, B. 2005. "Vom »Feldmarschall« zum »Eroberer«. Über den Einfluss der österreichischen Theaterzensur auf den Spieltext in der zweiten Hälfte des 19. Jahrhunderts". Internationales Archiv für Sozialgeschichte der deutschen Literatur 30. 98 117.

Tumfart, B. 2008. ““... aus fremden Gärten in unsern deutschen Boden von mir verpflanzt'. Ignaz Franz Castelli als Übersetzer französischer Theaterstücke”. Übersetzen im Vormärz. Jahrbuch 2007 = Forum Vormärz Forschung 13. 85-116.

Tumfart, B. 2012. "Eugène Scribes Theater im Taumel der Gefühle. Emotionen in deutschsprachigen Übersetzungen des 19. Jahrhunderts". Nestroyana 32. 146-162.

Watkins, C. 2001. How to kill a dragon. Aspects of Indo-European poetics. Oxford: Oxford University Press.

Yates, W.E. 1972. Nestroy. Satire and parody in Viennese popular comedy. Cambridge: Cambridge University Press.

Yates, W.E. 2008. "Continuity and discontinuity in Viennese theatrical life from the 1860 s to the turn of the century". Austrian Studies 16. 51-68.

Zemskaja, E.A. 1973. Sovremennyj Russkij Jazyk: Slovoobrazovanie. [Contemporary Russian: Word formation]. Moskva: Prosveščenie.

Address for correspondence:

Wolfgang U. Dressler

Institut für Sprachwissenschaft

Universität Wien

Sensengasse 3a, 1090 Wien

Austria 